\title{
UNDERSTANDING THE ROLE OF ORGANIZATIONS IN THE OCCUPATIONAL STATUS OF INDUSTRIAL DESIGNERS THROUGH THE EXPLORATION OF DRESS AND APPEARANCE NORMS
}

\author{
Pinar KAYGAN*
}

Received: 09.12.2012; Final Text: 03.06.2013

Keywords: Industrial design; interdisciplinary work; occupational status; ideal worker.
* Department of Industrial Design, Faculty of Architecture, METU, Ankara, TURKEY.

\section{INTRODUCTION}

The lower prestige and recognition of the designer's work has been paid considerable attention in research on professional practice of design. Some studies within this field have shown that designers hold a disadvantaged status compared to their non-designer colleagues in interdisciplinary work settings (see for example Molotch, 2003 for the context of US). Other studies have underlined the highly restrictive career structure for designers in terms of both their roles within the organizations in which they work, and the level of remuneration (see for example Frayling, 1996; Smith and Whitfield, 2005). In these studies the low professional status of designers has been linked to the lack of a specialized, well-established and recognized body of knowledge, unlike occupations such as medicine, law, engineering and architecture (see Smith and Whitfield, 2005 for a comprehensive discussion). The picture delineated in these studies demonstrates the persistence of the lower status of design in business world, where, as Gorb $(1990,2)$ indicates more than two decades ago, design has always suffered from its perception as "a 'soft' activity linked to creative and unquantifiable" compared to other professional fields.

Although the existing literature enables us to see that designers, as an occupational group, have limited access to power and privilege in multidisciplinary work environments, we do not know much about the organizational processes through which they are distanced from higher, especially managerial, positions in these environments. This article addresses this gap by examining the organizational contexts where industrial designers' work require collaboration with engineers and marketing people through the new product development process. Drawing on the experiences of industrial designers in such interdisciplinary contexts, it aims to understand how and in what ways their lower occupational status is constructed and sustained, as well as challenged, in organizations. 
In order to set the conceptual framework within which I explore this question, I turn to feminist literature on work. This literature provides us with a useful concept to investigate the power relations in organizations: the 'ideal worker' image. In what follows I will first introduce this concept. Then, I will narrow my focus on one aspect of the ideal worker image, namely, dress and appearance norms, and discuss what makes these norms significant for the study of power relations in the workplace. After introducing the research design, the findings will be presented in three sections. The article will conclude with remarks on the implications of dress and appearance norms and the power relations organized around them for understanding the lower occupational status of industrial designers in interdisciplinary work environments.

\section{THE 'IDEAL WORKER' IMAGE AND DRESS AND APPEARANCE NORMS AS ONE OF ITS ASPECTS}

Studies of the last few decades which are concerned with inequalities at work have proved an important corrective to the assumption that jobs are 'empty slots' and organizations are neutral organisms which offer equal opportunities to anyone (Acker, 1990, 2006; Martin and Collinson, 2002). Instead, these studies have argued, every occupation has strong associations with certain images that prescribe the traits, skills and qualities that an ideal member of that occupation is expected to possess (Peterson, 2010). For example, the ideal image of the professional worker, particularly for managers, is generally aligned with traits such as competitiveness, rationality, aggression and technical competence (Demaiter and Adams, 2009). These ideal images are influential on various organizational processes such as recruitment, assessment and promotion of workers. Workers who conform to ideal images are rewarded with higher and more powerful positions in the organizational hierarchy, whereas those who do not are considered to be relatively unsuitable for such positions (Kelly et al., 2010; Bird, 2003).

Studies that focus on occupational contexts show that ideal images are embedded in not only the organizational, but also the occupational culture. They are manifested in the jargon, narratives and informal relations between the members of that occupation. Examining engineering students, Dryburgh (1999), for example, demonstrates how students encounter the ideal image of the engineering professional at school, and learn to take on the identity of the engineer in line with this image, which she summarizes as 'work hard, play hard'. In a similar vein, Faulkner (2007) argues that the ideal image of the engineer is strongly associated with technical competence, the 'mastery of nature', and practical and scientific expertise. She underlines that although the actual practices in engineering can diverge significantly from this image (i.e. that social competence becomes an important aspect of the engineer's work particularly in managerial roles), it is still privileged by the members of the occupation as it empowers them over other professionals they collaborate with, in whose expertise reliance on science and maths is not underlined in the same strength. Thus, the ideal worker image sets the standard for powerful positions in one specific (occupational and/or organizational) context, even though this image does not always overlap with the actual practices of workers in these positions.

As the above two studies illustrate, the general tendency in the existing studies is to focus on the nature of expertise in the exploration of the 
ideal images (Kelan, 2008). In this paper, however, I argue that dress and appearance norms should be taken into consideration as another significant, and the most visible, aspect of the ideal worker image, and a critical investigation of the issues around these norms can help us expand our understanding of the power asymmetries between different occupational groups. This argument relies on, first, my observations during the interviews I conducted with industrial designers on their work experiences for another project. Although the focus of the interviews was not on dress and appearance norms, participants placed considerable emphasis on the significance of these norms in the discussion of how their profession is perceived by both their managers and non-designer colleagues. Such an emphasis in their accounts encouraged me to carry out a systematic investigation of these norms as an aspect of the ideal worker image.

Secondly, what makes these norms fruitful for the study of power relations in the workplace is that how workers look carries significant symbolisms regarding their competence and suitability for certain roles (Kang et al., 2011; Rafaeli and Pratt, 1993). Business attire is a good example for this argument, since, as highlighted in many studies on gender and work, it has strong connotations of higher authority and professional status (Collinson and Hearn, 2005; Lester, 2008). It has a significant influence on how its wearer's work is perceived by others. Simpson's (2009) research, for instance, shows that secondary school teaching is perceived as a more professional job in comparison to primary school teaching, since for the former being in suits invites being perceived as being experts in certain subjects, and therefore doing a 'serious' job. The latter, on the other hand, has a 'non-serious' image due to the casual dress norms that its members adopt. Although both are professional jobs, the symbolic associations that suits bring along reinforce the notion of 'being experts' in the former's image.

Pratt and Rafaeli's (1997) study with nurses working in two different units follows a similar argument, but places more emphasis on workers' choices of dress and appearance. Nurses working in the rehabilitation unit prefer wearing casual dress because, according to them, it is associated with the environment outside of the hospital and patients' being ready for this life. Nurses working in the acute care unit, on the other hand, believe that they should wear scrubs which connote professional work and competence. Views of 'appropriate' attire among workers thus is not incidental, but is closely linked to how members of an occupation define their role within the organizational context. Various, even contrasting, dress and appearance norms can be adopted by different members of an occupation, in line with the image that they wish to present as the ideal.

Considering these arguments on dress and appearance norms and work, in this article I formulate my empirical questions as follows: What kind of dress and appearance norms are shared among industrial designers? What is the link between these norms and industrial designers' occupational status in interdisciplinary work settings? In the following section I will discuss the research design adopted to investigate these questions. 


\section{RESEARCH DESIGN}

\section{Narrative Research}

In this study interview-based thematic narrative research is employed as a method. To define briefly, in this paper, narrative is understood as the "biographical particulars as narrated by the one who lives them", which correspond to an extended account that focuses on a significant aspect of one's life (in this case 'work') and which are elicited specifically for this research through in-depth interviews (Chase, 2005, 651). Whilst the terms 'story' and 'narrative' are often used interchangeably, some narrative researchers suggest that they are not the same, indicating that narrative is a more general concept, whereas stories have coherent plotlines or characters (Cunliffe et al., 2004; Czaniawska, 2004). I find it useful to distinguish between these two terms and use story for each single unit of analysis, which describes a single event or incident. Narrative, on the other hand, corresponds to the whole product of the interview, which has its own structure in itself. In other words, I take narrative as the personal account of a participant and fragment it into stories to create units of analysis, which will be analyzed in relation to the contextual particularities of that narrative.

Narrative research has attracted considerable interest in organization studies (Boje, 1991; Boyce, 1995; Czarniawska, 1997, 2004; Fineman, and Gabriel, 1996; Gabriel, 2000; Simpson, 2008). In these studies creating, telling and negotiating stories are considered key processes through which the members of an organization make sense of their experiences within that organizational context. It is suggested that through studying narratives in organizations, the researcher can collect and compare different accounts, understand the organizational culture and gain access to deeper organizational realities, which are closely linked to their members' experiences (Gabriel, 2000). Similar to organizations, occupations also provide significant narrative environments due to shared skills, orientations, objectives and outlooks they contain. Gubrium and Holstein (2009) indicate that professional occupations in particular supply highly developed and distinctive interpretive tools, as they have well-established formal cultures, tend to require greater investments for membership and impose themselves in the form of lifestyle. Narratives elicited in a professional environment, then, reveal common and contradictory concerns, perspectives and interests in the occupational and organizational contexts.

The subjective, contextual and situated nature of narrative is considered its main weakness by some scholars on the grounds that a narrative may not reflect the participant's feelings and attitudes as they would be expressed outside the interview setting (Halford et al., 1997). However, this contextuality is accepted as the most important strength of narrative, by narrative researchers who are working from a social constructionist approach in a similar vein as myself (Czarniawska, 2004; Riessman, 2008). As Elliott $(2005,26)$ notes,

A narrative will not capture a simple record of the past in the way that we hope that a video camera might. However, if the research focus is more on the meanings attached to individuals' experiences and/or on the way that those experiences are communicated to others then narratives provide an ideal medium for researching and understanding individuals' lives in social context. 
Rather than describing what 'exactly' happened, narratives serve the narrator as a means of evaluating the past and present, anticipating the future and communicating these evaluations and anticipations (Cotteril and Letherby, 1993). Sharing this view, in this paper, I am interested in the meanings that participants attach to their stories regarding dress and appearance at work, including their preferences as well as the codes they are expected to conform, rather than what they 'really' do and/or should wear.

A second issue regarding narrative research is that as a case-centered method it interrogates cases rather than population-based samples. As a result, it is difficult to generalize findings of a narrative study to the entire population. However, Flyvbjerg (2004) underlines that statistical generalization is not the only valid and desired outcome of research, and the rich, in-depth and context-dependent models of research are also essential to the development of new theories. In case-centered research, the question changes from "whether interview findings can be generalized globally" to "whether the knowledge produced in a specific interview situation may be transferred to other relevant situations" (Kvale and Brinkmann, 2009, 261-62) Also, Riessman $(2008,13)$ argues against the assumption that the results of case-centered studies are not transferable, stressing that "making conceptual inferences about a social process (the construction of an identity group, for example, from close observation of one community) is an equally 'valid' kind of inquiry". Thus, theoretical, if not statistical, generalization is possible in narrative research.

\section{Collecting and Analysing Stories}

Within this methodological approach, empirically this paper draws on the stories collected through in-depth interviews with 12 men and 20 women industrial designers with work experiences in ten different cities in Turkey. The three tables below, Table 1, $\mathbf{2}$ and 3, which aim to provide a summary of the interview sample in terms of key characteristics, were compiled from the background data I collected both before and throughout the interviews.

As Table 1 demonstrates, 19 of 32 participants have entered professional life after 2000. One of the participants graduated between 1981-1990 was retired, and another one graduated between 1991-2000 had left industry to become an academic after six years' experience. Apart from these two, all participants were still working, either as in-house or self-employed designers. Some of them experienced both forms of employment, as Table 2 shows below, during their careers.

As Table 2 shows, most of the participants had work experiences as in-house designers in manufacturing companies. This was a purposive selection as in-house industrial designers' experiences would be more

Table 1. Participants' distribution according to graduation year from university

Table 2. Participants' distribution according to form of employment

\begin{tabular}{|l|l|l|l|}
\hline Graduation year & Number of women & Number of men & Total \\
\hline Until 1980 & 1 & 1 & 2 \\
\hline $1981-1990$ & 4 & 1 & 5 \\
\hline $1991-2000$ & 3 & 3 & 6 \\
\hline $2001-2005$ & 12 & 7 & 19 \\
\hline
\end{tabular}

\begin{tabular}{|l|c|}
\hline \multicolumn{1}{|c|}{ Form of employment } & Total \\
\hline In-house (in manufacturing companies) & 21 \\
\hline Self-employed (in design consultancies) & 3 \\
\hline Experienced both forms of employment & 8 \\
\hline
\end{tabular}


productive for a research that aims to investigate interdisciplinary work contexts. The definition of the interdisciplinary work may vary depending on the scale of the organization and the industrial sector, i.e. in largescale companies, new product development process requires designers to collaborate with production engineers and marketing people throughout the project, whilst in small-scale companies they usually take project decisions with the owner of the company, who is a non-designer. Still, in-house designer's work usually includes interdisciplinary relations in manufacturing companies, as was the case with these 29 participants. The three self-employed participants also experienced project-based interdisciplinary relationships with the engineers and/or marketing people in different hierarchical positions in their client companies. However, these participants were not concerned with their occupational status much, since being consultants who own their design firms, they already felt themselves in a powerful and privileged position in these relations. This is why although during the analysis the three self-employed designers' narratives were also examined together with in-house designers', they did not contribute to the findings of this paper.

Whilst 15 participants (12 in-house, 3 both) have worked for one single industrial sector, 17 participants have work experiences in more than one industrial sector. I show the industrial sectors for which participants have worked during their professional lives in Table 3 below, where I classified the industrial sectors according to the product classification of Industrial Designers Society of Turkey prepared for Design Turkey Industrial Design Awards (Hasdoğan, 2012).

At the beginning of the interviews I explained to the participants that I was expecting them to tell me what they went through in their professional lives starting from their graduation day until the time of the interview; and that in this, it was important to consider interdisciplinary relations. I also highlighted that I was particularly interested in their experiences in the form of stories rather than opinions and thoughts, and informed them about how I was going to use the information they provided. The interviews lasted from 45 minutes to two hours.

\begin{tabular}{|l|c|}
\hline \multicolumn{1}{|c|}{ Industrial sector } & $\begin{array}{c}\text { Number of } \\
\text { Participants }\end{array}$ \\
\hline Furniture & 11 \\
\hline Packaging & 4 \\
\hline Lighting & 1 \\
\hline $\begin{array}{l}\text { Electronic equipment } \\
\text { (inc. electronic consumer goods and communication devices) }\end{array}$ & 5 \\
\hline $\begin{array}{l}\text { Electrical household devices } \\
\text { (inc. white goods and kitchen appliances) }\end{array}$ & 1 \\
\hline Transportation & 4 \\
\hline $\begin{array}{l}\text { Capital goods } \\
\text { (inc. devices for professional purposes, i.e. military products and } \\
\text { funfair machines; and construction machines and tools) }\end{array}$ & 5 \\
\hline $\begin{array}{l}\text { Home and office accessories } \\
\text { (inc. kitchenware and glassware) }\end{array}$ & 5 \\
\hline $\begin{array}{l}\text { Sports, hobby, game, and personal products (inc. jewellery, bags, } \\
\text { and other fashion accessories) }\end{array}$ & 5 \\
\hline $\begin{array}{l}\text { Building components } \\
\text { (inc. sanitaryware, heating devices, electrical fittings, and related } \\
\text { furnishing products) }\end{array}$ & 6 \\
\hline
\end{tabular}


My overall approach to analysis was interpretive, which means that my focus was on the meaning, and went beyond a literal reading of the data (Riessman, 2002). In the first stage of the analysis I transcribed the tape-recorded material. Then I read through the transcripts of narratives individually in order to identify stories around dress and appearance norms/preferences which constituted the units of analysis. Once stories were selected, they were analyzed thematically. Here it is important to note that although thematic narrative analysis seems very similar to other interpretive qualitative methods, it is differentiated by the fact that it preserves stories intact and analyzes them as cases rather than fracturing them into segments to be coded (Riessman, 2008). This aspect of narrative analysis led me to use a visual mapping tool instead of a line-by-line coding software. I chose Visual Understanding Environment (VUE), an open-source mind-mapping software, which I used to create an individual map for each transcript. In these maps, each box represents a story, including my interpretation of the story and the notes I took in the course of the interview. Then, these boxes were clustered around emergent themes. After creating a map for each participant, I looked for the commonalities and differences across the 32 maps to understand what is shared and what is not, and more importantly, how and to what extent individual concerns can be used to construct a collective narrative. In this paper, stories from 11 participants are chosen to illustrate the major themes due to length issues. In this, statistical significance has not been sought due to the research approach employed and the small sample size. In the quotes, all participants are given pseudonyms and the interview extracts used in the article are my own translation from Turkish.

\section{The Context of the Study}

The questions of this study are investigated in the context of Turkey. Industrial design has a short history in Turkey. Industrial design in Turkey appeared in the educational field before the industry, first as a part of architecture education, and then as a separate discipline with the foundation of industrial design programs in educational institutions in the 1970s (Er et al., 2003). The emergence of education before a demand for industrial designers was established in industry is pointed to as the reason for the lack of the promotion and recognizability of the industrial design profession in Turkey, which affected the development of the design profession from the very beginning (Korkut and Hasdoğan, 1998). Since Turkish industry had no interest in new products in the absence of a competitive environment, the need for an industrial design profession was under debate until the end of the 1980s (Er, 2002). Industrial design graduates, thus, had to work in jobs which were unrelated or partiallyrelated to their profession such as graphic design and interior design.

Demand for industrial design initially came from large-scale manufacturing companies in automotive, durable consumer goods and electronics industries in the 1990s after export-oriented industrial production and liberal economic growth policies resulted in a more competitive environment for Turkish industry. By the beginning of the 2000s small- and medium-scale companies (SMEs) also showed interest in original designs, rather than imitating and replicating existing products (Özcan, 2009). In these companies industrial design is mainly utilized to differentiate among competitors by visual and formal features of their products. Thus, industrial design profession gained prominence and became popular in Turkey in the last decade (Hasdoğan, 2009). 
Although the existing design literature on Turkey highlights industry's recently increasing interest on industrial design, we do not know much about whether the industrial designers in Turkey share the lower occupational status compared to other disciplines discussed at the beginning of this paper. Therefore, first there is a need to establish the current situation in the Turkish context. To this end, before moving to a discussion on dress and appearance norms, I start the analysis by investigating to what extent and in what ways power asymmetries in interdisciplinary relations appear as an important concern in the participants' stories.

\section{STATUS OF INDUSTRIAL DESIGNERS IN INTERDISCIPLINARY WORK CONTEXTS}

Regarding interdisciplinary work settings, in the analysis three main concerns, closely linked to each other, were identified. First, the stories show that the industrial designer's job is not seen as important as that of engineers and marketing people by their non-designer employers. It is not seen as part of the core business that is indispensable for the company. Second, and as a result of this, designers are not paid as much as their counterparts in engineering and marketing, at any levels of their career. The following story told by Cengiz, a male freelance industrial designer, illustrates both of these concerns.

Demir is an engineer colleague of mine from my previous workplace. When he left there, he launched his own business. Well, they're designing home security and smart home systems. And he wanted me to do the hardware side of the project. First I said, "OK", but later we noticed that it was actually all engineering work. And my wife, Esin, is an engineer. She told me, "I can do this very easily". Anyway, we spoke with Demir and said, "Esin will do the [mechanical] design work, and I'll deal with the visual form". Esin said, "My price is 3,000 liras". He said, "OK", without much thought. And I can say that she gave this work a total of three days, including checks and later corrections. And she took 3,000 liras for this. Later Demir told me, "Our software needs a user interface". So I said, "I'll do it for 3,000 liras". But Demir found it expensive. "Never mind, it's too much for us", he said. [Later he himself did the interface design.] And they had such a horrible interface in the end. They've made icons out of photographs they downloaded from the Internet! You know, he found the price for the interface [design] too much, but I was going to spend my month for it. Esin earned the same money in three days and they didn't even find it expensive. I mean the work we do is not visible at all. I don't know, do they think we just make it up and say "I made a design"?

This story well exemplifies how valuable the engineer's work is as opposed to that of the industrial designer. Cengiz complains that even though the work he would do was more labor-intensive and time consuming when compared to Esin's, it was underestimated by Demir. Demir immediately accepted the amount Esin charged, whilst he attempted to create the user interface himself without consulting a professional designer to minimize the expenses of the project. This shows Cengiz that according to Demir, industrial designer's work is not only less valuable, but also less professional and easily dispensable.

Thirdly, participants' stories indicate that available managerial positions are limited for in-house industrial designers. This means that designers are usually overseen by non-designers at the upper levels of management, whilst they cannot become, for example, the director of the Research and 
Development Department when it includes engineers as well as industrial designers. As Seher argues below, like in the previous story, this is also because the engineer's contribution and work is valued over the designer's.

We are one grade lower than engineers. I mean, we don't get the money engineers get. We fought for it, too. You know, we have a four-year degree, too, and it was our choice to study it. I mean, [we had studied design] not because we are inferior. Or the company doesn't benefit less from us. I mean, we tried to express this. But the company's approach to industrial design is - It seems they don't think they will benefit much from you, so you are deemed worthy of one grade lower than engineers.

Esra also described the situation in the company from which she retired after two decades. According to her, the main concern of the top management was to prevent designers from being managers of engineers.

Engineers are promoted, say, every five years, whilst designers are promoted every seven or eight years. And there are only three grades available for designers, they can't rise further. We had a lot of arguments. When I was the manager [of the design team], I got involved in writing those procedures. I would write the standard thing: a procedure of promotion process that consists of five grades. It would go to upper management, three [highest] grades would immediately be deleted, saying that a designer can't rise that much. This is because in these grades you become a manager, and as a manager you can have engineers under you. It is not to give you [such an opportunity].

In line with the studies examined above, which have been concerned with the lower prestige and recognition of design professions (Molotch, 2003; Smith and Whitfield, 2005), there was a consensus among all of the participants who worked as in-house designers in manufacturing companies on that designers' lower status in the organizational hierarchy was closely related to how their occupation was perceived by those outside of the occupation. Although, as I discussed somewhere else, this perception is also shaped by non-designers', especially engineers', view of design as a subjective and 'arty' work (Kaygan, forthcoming; Gorb, 1990), in this paper I deal with the question of to what extent and in which ways participants consider dress and appearance norms shared among industrial designers relevant to this perception of their occupational image - the image that is associated with their occupation.

\section{DEFINING AN UNCONVENTIONAL OCCUPATIONAL IMAGE FOR THE INDUSTRIAL DESIGNER}

In the stories there is a certain occupational image ascribed to industrial designers, which was described as 'ideal' by some participants, whilst criticized by others, as I will demonstrate in the following two sections. According to the definition of this image, as creative people, designers are supposed to have a 'designerly' way of speaking, working and dressing. They are assumed to need less restricted conditions in the workplace so that they can express themselves freely. This freedom provides a lot of flexibility with regard to, especially, dress and appearance norms. Designers are not usually expected to be stuck in formal dress and shaved or have made-up faces. Unlike their non-designer colleagues, they could enjoy casual dress - even, in some organizations, shorts, t-shirts and trainers. For example, Banu, a furniture designer, who was in jeans and a t-shirt when I went to her office to interview her, said: 
For example, jeans aren't allowed here, or in my previous workplace. But when you wear jeans, [they don't ask you] why you wore them; even if they make cynical remarks sometimes, they can accept it. But it becomes a bigger issue if a marketing person wears jeans. But of course you do this within certain rules. For example in my previous workplace, I don't think they had employed many designers before us. [So] when we went there, all young people, all in jeans, they said that we designers were like people selling stuff on the street. (laughs) But then because of the designers the company's mood has started to relax, too. [...] Designers look more casual, their behavior is more casual, they talk more casually when compared to other people. I don't know whether other people gain anything from this, but for example some of them who work with a civil servant mindset are inspired by the designers who don't.

In this example designers, as a group, introduce themselves to the company with this casual culture. Management is convinced that this is what being a designer means and allows them to bring this image into the organization even though it is not completely approved of in the organizational culture. It seems that Banu considers the way designers present themselves a resistance or even an intervention to the conservative image of the whitecollar worker, the 'civil servant mindset'. Designers can set their own rules and create a privileged space for themselves. But everybody knows that it is definitely a privilege that belongs only to designers. Even after the designers' arrival changed the atmosphere of the workplace, non-designer white-collars would still not be tolerated for leaving suits and wearing jeans, since this would be inappropriate for their positions.

Ozan is another designer who champions this casual image. Working in the automotive industry, he stated that in the company in which he works, there are neither any formal dress codes that workers have to follow, nor any preferences expressed by managers regarding workers' dress and appearance. Despite this freedom, in this engineer-dominated work setting he is the only worker who grows an unusually shaped beard and wears jeans and t-shirts. He believes that 'being different' is an important aspect of the occupational image of industrial designer and adopting this image marks him as a successful designer. He said,

Of course you attract attention, whether you like it or not. It's something that I do purposefully, actually something that I want, too. Here [in this company], for example, my relationship with the bosses can be more favorable. This is because they know you're a creative, that you are a different person from the others, so they treat you differently, they're curious about you.

As a designer, Ozan is not only allowed to adopt such an unconventional image, but further valued for this. In contrast to engineers, he is encouraged by his directors to bring the subjective and creative aspects of his personality to the workplace, because this is perceived to be the requirement for being a successful designer. So, although within the context of the previous story this image appears as a collective coping strategy developed by designers for creating a space to avoid the restrictions of professional life within certain limitations, in Ozan's story it matches the ideal image of the industrial designer in the organizational culture.

Thus, adopting a casual dress style does not merely mean wearing informal clothes. It also includes adopting stylistic preferences, which express designers' individual taste, creativity and difference from other people. Deniz indicated that in the job interview the general manager was 
surprised to see her and the other designer, Zuhal, look like 'ordinary' people.

In her job interview the general manager told Zuhal, "I was expecting you to have blue hair, but you aren't like that," and so on. There were such dialogues in my [job interview], too. People outside our discipline really think that we are extraordinary people.

Nevzat, another furniture designer, also appreciates the privileges that this distinctive occupational image brings to him. He says,

Nevzat: If you're a designer, for example when [in my previous company] they introduced a dress code, I never complied with it and nobody asked me why I didn't. People have these foolish assumptions about the designer, like "they're designers, of course they'll be carefree". They have these silly assumptions. This makes you comfortable. I mean, these assumptions make you comfortable in other cases, too.

Researcher: For example?

Nevzat: You can distance yourself from some of the official things. Say, if it's about the bureaucratic side of the work, you can lie and say that "I can't do it, I don't know how to do it." I said that a lot, both [in my previous company] and here.

Unlike Banu and Ozan, Nevzat is not excited about the assumption that 'a designer should be carefree'. Rather he depicts it as a 'silly assumption' with no grounds. Still, he does not complain or fight it and instead takes advantage of this assumption. The casual image of the industrial designer enables him to be free from the dress codes which other professional workers have to follow. His exceptional appearance implies a distinct occupational role in the organization, with negotiable roles and responsibilities. He can easily deliver bureaucratic tasks to a non-designer. Neither does he hesitate to say that he is not capable of doing paperwork, nor does this make him an incompetent professional for his employers. Being an industrial designer, he is already considered to be different and he does not have to conform to the image of the conventional professional worker in terms of both appearance and the working style. Like in Ozan's story, in Nevzat's story 'being different' appears as a strong theme, too. But the latter is distinguished from what we see in the former, since in the organizational context of the latter 'being different' is not an expectation or a privilege that is linked to the ideal industrial designer image by the management. Rather, it appears as a coping strategy against the mundane requirements of the working life, in a similar vein to what we encounter in Banu's story.

Stories examined in this section emphasized the advantages that the unconventional occupational image of industrial design offers to its members. According to these stories, it brings designers much flexibility in terms of dress and appearance norms, relationships and responsibilities, albeit in different ways, to which their non-designer colleagues do not have access. In the next section I will shift to the stories which are generated with reference to the organizational contexts in which this image is considered an obstacle for managerial positions.

\section{COMPETING FOR MANAGERIAL POSITIONS}

Recalling his experiences in his previous workplace, Kerem indicated that there, all designers used to dress in a casual style. Only the team leaders, he 
said, would "try to" wear shirts and more formal trousers instead of jeans. However, regarding engineers he said,

Kerem: [Engineers] always wear formal trousers and shirts. I mean, it's always a bit like that. Engineers, also in the company where I work now, dress rather in this way. I don't know why. Actually no one forces them to do so.

Researcher: Do you mean they can dress as you do if they like?

Kerem: They can. Actually they do sometimes. But I think it's like a secret agreement. I mean there is this idea, coming from somewhere, that anyone who wants to be manager should dress more properly. And it's like, the people who get that [message] say, "Yes, I want that, too!" and start behaving accordingly.

Saying this, Kerem underlines the relationship between dress choices and one's image as a professional worker. His story suggests that when it comes to competing for managerial positions, one has to adopt the ideal image of the professional manager to be considered suitable for such positions. Engineers, who mostly dominate managerial positions in the company, pay attention to presenting themselves in business dress, which creates a corporate impression, and establishes the image of its wearer as business-oriented (Dellinger, 2002).

Whilst in Kerem's story professional workers' dress and appearance norms are shaped by the ideal images within the organization in a subtle way, in Sedef's story we see an explicit intervention of the management. She describes how her unconventional image is appreciated as long as she is within the borders of the design office, but seen as an improper way of presenting oneself in the formal environment, i.e. in the meetings with managers. Like her, some of the other participants also stated that they dress more formally when they attend a meeting in the company with managers or outside the company with customers. Sedef said,

Now we have this freedom and of course we often make use of it. (...) It has its advantages. I mean, as I said, because they view us as artists, they say things like "You are creating [things]." But of course we should put it in this way: It's like this when you're chatting with colleagues, but when it's about business - (...) I mean, when you wear something beautiful, different, they say "Oh, it's beautiful". But when you attend the meeting, they say, "I don't want this, go change."

The incompatibility between the casual image of the industrial designer and the formal image of the ideal professional worker was raised, especially by the participants who work in large-scale and corporate companies. They argued that the way in which industrial designers present themselves was highly influential on their mismatch with this image and it is the reason behind their inferior status in interdisciplinary work environments. In order to cope with this situation, they suggested that designers should replace their casual clothes with business attire, and look like 'one of them'. For example, Hatice described how, in the last couple of years in her workplace, the dress norms for designers had changed dramatically from shorts and sandals to suits, through the efforts of the leader of the design team.

They say that the designers before us used to wear shorts, come to work with sandals and so on. Everyone says they were crazy, they were just that way... But people also liked their being that way. They used to say, "This is what we are," and come to work in these clothes. But the current leader of the design team, Bora, believes that the person you call a designer has to 
express herself, so she should dress smartly. When you attend a meeting, who will take you seriously if you go there wearing sandals? Then you would only be the producer, the creator. But you are also managing, leading things. But, he thought, if you do that, you can never become the boss. This is why he always wore his suit, always wore his tie, you know, he always tried to dress properly.

In this story, like Kerem's, business dress is presented as the symbol of competence for managerial roles. The casual dress style is posited as the very obstacle that prevents industrial designers from looking appropriate for managerial positions, although designers have nothing less than their non-designer colleagues in terms of skills and competence. The only problem is that designers do not know how to 'sell themselves'. Nondesigners, on the other hand, match the image of the ideal professional manager in their suits, which convey higher authority and professional status (Collinson and Hearn, 2005; Rafaeli and Pratt, 1993). Therefore, replacing the casual dress with suits, Bora displays the look of the ideal professional worker, which makes him seem not only capable of designing things, but also competent enough to take part in managerial and leadership roles, like the engineers in Kerem's above story.

Leman supports this argument. She works in a large-scale company. When we met for the interview in her office she was on the verge of becoming the leader of the design team. She said that it was an interesting time to talk about her job, as the design department was being reshaped and repositioned in the organizational structure. From then on, designers would take a more important role in product development processes. This was a big step for the industrial designer's position in the company, and like Bora, Leman believes that looking like 'one of them' has been the key to take this step.

[In this company] there is this attitude of, you know, darker dresses, more formal dresses, like the one on me right now. It's not very strict but [managers] have their expectations. What would happen if I dressed [more casual]? I don't really think that my director would say anything to me. But when you go to a meeting, it really gives rise to prejudice in people, and things like not taking the designer seriously. Like, "They are designers, they live on top of the clouds, they live in a different world". I mean, to make them realize how much they profit from the designer's services, it's useful to look a bit like they do. Otherwise they are a little bit afraid of the designer. They don't think that the designer can do work. They think that the designer just draws well, says stuff, and that's all. But I mean, if engineer does the technique, manufacturing person does manufacturing, marketing person does marketing, what is designer going to do?

Leman's account reiterates that 'who wears what' is highly influential on the assumptions regarding who does 'real' work and who does not in the interdisciplinary environment. Business dress is identified with "a work mentality" (Dellinger, 2002, 9). It marks non-designers as serious, competent and rational professionals whose work is valuable for the organization. Their image enables them to suggest that they are the ones who do the 'real' work, particularly when they compare themselves to the designers who look casual. In such an environment, designers' contribution is considered to be limited to 'making things pretty', thus, less important for the company as stated as the main concerns regarding the lower occupational status of industrial designers in the stories by Cengiz and Seher, presented in the first part of the analysis. 


\section{DISCUSSION}

Therefore, stories cluster around two main interpretations of the unconventional occupational image associated with industrial designers: In the first group of the stories, including the stories by Banu, Ozan and Nevzat, the emphasis was placed on the advantages that this image offers to designers. In these stories, this image brings along an alternative understanding of professional work and worker that does not have to comply with the existing norms in the organizational culture. In the stories told by the second group, consisting of Kerem, Sedef, Hatice and Leman, on the other hand, the incompatibility between this image and the ideal image of the professional manager is underlined. In these stories, this image is rather associated with 'less professional' and 'less serious' work and workers.

In the discussion of these two different interpretations, it is crucial to take into account the contextual specificities of these stories. The industrial designers in the first group work in the organizations where the product design process is carried out mainly by industrial designers within the design department. Since their positions are fixed, and they are reporting directly to the top management, which mainly consists of the owners of the company, in these organizations designers have no expectations for promotion to a higher role in the organizational hierarchy. Also, even though their job requires collaborative work with people from manufacturing and marketing departments, to a larger extent they work individually.

However, industrial designers in the second group work in large-scale companies where opportunities are available for climbing up in the organizational hierarchy. Unlike the situation in the first groups' cases, in these organizations design processes require intense and constant interdisciplinary work between industrial designers, engineers and marketing people. Professionals from each discipline come together in formal project meetings to discuss the process and the decisions taken throughout the process in the presence of managers and directors. As reflected in the stories, in these organizational contexts it is mostly engineers and marketing people who take part in the management, and the ideal images shared in these disciplines also shape the image of the ideal professional manager, i.e. the serious and formal worker in suits. As a result, in these stories for the workers it becomes more crucial to merge into the organizational culture in order to be considered an appropriate candidate in the competition for managerial positions.

In light of these findings then we can see that the attitudes towards the unconventional image of industrial design are shaped by first, the ideal images promoted and privileged by the management, and second, the nature of the interdisciplinary relations facilitated in the organizational culture.

\section{CONCLUSION}

This paper focused on the arguments around dress and appearance norms shared among industrial designers in various interdisciplinary work contexts in order to underline how these norms and the power relations between industrial designers and other disciplinary groups are linked. Doing this, it revealed that organizations play an important role in the construction of the disadvantaged professional status of industrial design 
in so far as they sustain competitive interdisciplinary relationships among engineers, marketing people and designers.

This conclusion highlights the shortcomings of the existing approaches to the management of interdisciplinary design teams. Although conflicts between various disciplinary groups who take part in design processes have been discussed by the existing studies, these studies have mostly ignored the power asymmetry between these groups. Rather in them the general tendency is to describe these conflicts as a natural consequence of different disciplinary interests, priorities and educational backgrounds. For instance, to exemplify the conflicts between industrial designers and engineers, Cagan and Vogel (2002) refer to a story in which the narrator, an engineering manager, presents the engineer in the role of a parent and designer in the role of a child who does not listen to his (sic) parents. In the story the latter attempts to spend more money than he has only to buy the biggest and the most impressive basket of candy. In their interpretation of this story, Cagan and Vogel are only interested in the differences between the priorities of the two professional groups, and the 'perceptual gaps' created by these priorities. In this manner, they disregard the power asymmetry embedded in the child-parent metaphor used by the manager. Such an understanding places much emphasis on minimizing these conflicts by enabling collaboration and communication, which are assumed to be achieved by mutual trust and respect, and sharing knowledge (Gray and Hughes, 2001; Persson and Warell, 2003), and on developing tools and methods to this end (Eujin et al., 2011).

The findings of this study, on the other hand, show that these conflicts are created via more complex (and less innocent) organizational processes than we can explain by mere 'disciplinary differences'. In order to overcome such conflicts, therefore, management of interdisciplinary teams should aim to create a more egalitarian atmosphere, in which the unconventional occupational image of the industrial designer or any other creative worker is as equally valued as the competitive, formal and serious image of the generic professional worker. Such an atmosphere would not only contribute to improving industrial designers' status at the organizational level, but can also encourage alternative understandings of 'being a professional' among non-designers. Only then we should expect to observe productive collaboration and willingness to adopt common tools and methods between occupational groups with different, even contrasting, images and cultures.

This paper argued that dress and appearance norms are an important aspect of the ideal images associated with certain positions. However, as the stories demonstrated, ideal images are not fixed, but rather contextdependent. Thus, this paper does not intend to define an ideal image with certain dress codes for industrial designers. It rather utilizes this critical concept to start a fresh discussion regarding the disadvantaged occupational status of industrial designers. Further research with managers of interdisciplinary new product development teams as well as non-designer professionals in such teams, especially those who support alternative understandings of 'being a professional', can help us elaborate on and deepen this discussion taking into account different perspectives. 


\section{REFERENCES}

ACKER, J. (1990) Hierarchies, Jobs, Bodies: A Theory of Gendered Organizations, Gender and Society, (4:2) 139-58.

ACKER, J. (2006) Inequality Regimes: Gender, Class, and race in organizations. Gender and Society, (20:4), 441-64.

BIRD, S.R. (2003) Sex Composition, Masculinity Stereotype Dissimilarity and the Quality of Men's Workplace Social Relations, Gender, Work and Organization (10:5) 579-604.

BOJE, D.M. (1991) The Storytelling Organization: A Study of Story Performance in an Office-Supply Firm, Administrative Science Quarterly (36:1) 106-26.

BOYCE, M.E. (1995) Collective Centring and Collective Sense-Making in the Stories and Storytelling of One Organization, Organization Studies (16:1) 107-37.

CAGAN, J., VOGEL, C.M. (2002) Creating Breakthrough Products: Innovation from Product Planning to Program Approval, Prentice Hall Inc., New Jersey.

CHASE, S.E. (2005) Narrative Inquiry: Multiple Lenses, Approaches, Voices, Handbook of Qualitative Research, eds. K.N. Denzin, Y.S. Lincoln, 3rd ed, Sage, Thousand Oaks, London and New Delhi, 65180 .

COLLINSON, D.L., HEARN, J. (2005) Men and Masculinities in Work, Organizations, and Management, Handbook of Studies on Men and Masculinities, eds. M.S. Kimmel, J. Hearn, R.W. Connell, Sage, Thousand Oaks, London and New Delhi, 289-310.

COTTERIL, P., LETHERBY, G. (1993) Weaving Stories: Personal Auto/ biographies in Feminist Research, Sociology (27:1) 67-79.

CUNLIFFE, A.L., LUHMAN, J.T., BOJE, D.M. (2004) Narrative Temporality: Implications for Organizational Research, Organization Studies (25:2) 261-86.

CZARNIAWSKA, B. (1997) Narrating the Organization: Dramas of Institutional Identity, The University of Chicago Press, Chicago, London.

CZARNIAWSKA, B. (2004) Narratives in Social Science Research, Sage, London.

DELLINGER, K. (2002) Wearing Gender and Sexuality “on Your Sleeve": Dress Norms and the Importance of Occupational and Organizational Culture at Work, Gender Issues (20:1) 3-25.

DEMAITER, E.I., ADAMS, T.L. (2009) ‘I Really Didn't Have Any Problems with the Male-Female Thing Until...': Successful Women's Experiences in IT Organizations, Canadian Journal of Sociology (34:1) 31-53.

DRYBURGH, H. (1999) Work Hard, Play Hard: Women and Professionalization in Engineering - Adapting to the Culture, Gender and Society (13:5) 664-82.

ELLIOTT, J. (2005) Using Narrative in Social Research: Qualitative and Quantitative Approaches, Sage, London. 
ER, H.A. (2002) Türkiye'de Endüstriyel Tasarımın Bir Geleceği Var mı? [Does Industrial Design Have a Future in Turkey?] Maison Françiase, (85) $170-71$.

ER, H.A., KORKUT, F., ER, Ö. (2003) U.S. Involvement in the Development of Design in the Periphery: The Case History of Industrial Design Education in Turkey, 1950s-1970s, Design Issues (19:2) 17-34.

FAULKNER, W. (2007) 'Nuts and Bolts and People': Gender-Troubled Engineering Identities, Science, Technology and Human Values (37:3) 331-56.

FINEMAN, S., GABRIEL, Y. (1996) Experiencing Organizations, Sage, London.

FLYVBJERG, B. (2004) Five Misunderstandings About Case-Study Research, Qualitative Research Practice, eds. C. Seale, G. Gobo, J.F. Gubrium, D. Silverman, Sage, London, 420-34.

GABRIEL, Y. (2000) Storytelling in Organizations: Facts, Fictions, and Fantasies, Oxford University Press, New York.

GORB, P., ed. (1990) Design Management: Papers from the London Business School, Architecture Design and Technology, London.

GRAY, C., HUGHES, W. (2001) Building Design Management, Elsevier, Oxford.

GUBRIUM, J.F., HOLSTEIN, J.A. (2009) Analyzing Narrative Reality, Sage, London.

HALFORD, S., SAVAGE, M., WITZ, A. (1997) Gender, Careers and Organisations: Current Developments in Banking, Nursing and Local Government, Macmillan, Masingstoke.

HASDOĞAN, G. (2009) The Institutionalization of the Industrial Design Profession in Turkey: Case Study - The Industrial Designers Society of Turkey, The Design Journal, (12:3) 311-38.

HASDOĞAN, G. (2012) Characterising Turkish Design through Good Design Criteria: The Case of Design Turkey Industrial Design Awards, METU Journal of the Faculty of Architecture (29:1) 171-191.

KANG, M., SKLAR, M., JOHNSON, K.K.P. (2011) Men at Work: Using Dress to Communicate Identities, Journal of Fashion Marketing and Management (15:4) 412-27.

KAYGAN, P. (Forthcoming) 'Arty' versus 'Real' Work: Gendered Relations Between Industrial Designers and Engineers in Interdisciplinary Work Settings. The Design Journal (17:1), 73-90.

KELAN, E.K. (2008) Emotions in a Rational Profession: The Gendering of Skills in ICT Work, Gender, Work and Organization (15:1) 49-71.

KELLY, E.L., AMMONS, S.K., CHERMACK, K., MOEN, P. (2010) Gendered Challenge, Gendered Response: Confronting the Ideal Worker Norm in a White-Collar Organization, Gender and Society (24:3) 281-303.

KORKUT, F., AND HASDOĞAN, G. (1998) The Profession of Industrial Design in Turkey: The Correspondence Between Education and Practice, IDATER 98 Proceedings, Loughborough University, UK, 12531. 
KVALE, S., BRINKMAN, S. (2009) InterViews: Learning the Craft of Qualitative Research Interviewing, 2nd ed., Sage, Thousand Oaks.

LESTER, J. (2008) Performing Gender in the Workplace: Gender Socialization, Power, and Identity Among Women Faculty Members, Community College Review (35:4) 277-305.

MARTIN, P.Y., COLLINSON, D. (2002) 'Over the Pond and Across the Water': Developing the Field of 'Gendered Organizations', Gender, Work and Organization (9:3) 244-65.

MOLOTCH, H. (2003) Where Stuff Comes From: How Toasters, Toilets, Cars, Computers, and Many Other Things Come to be as They are, Routhledge, New York and London.

ÖZCAN, A.C. (2010) An Overview of the Early Foundations and Development of Contemporary Industrial Design in Turkey, The Design Journal (12:3) 267-88.

PEI, E., CAMPBELL, I., EVANS, M. (2011) A Taxonomic Classification of Visual Design Representations Used by Industrial Designers and Engineering Designers, The Design Journal (14:1) 64-91.

PERSSON, S., WARELL, A. (2003) Relational Modes between Industrial Design and Engineering Design - a Conceptual Model for Interdisciplinary Design Work, Proceedings of the 6th Asian Design International Conference, Tsukuba, Chalmers University.

PETERSON, H. (2010) The Gendered Construction of Technical SelfConfidence: Women's Negotiated Positions in Male-Dominated Work Settings, International Journal of Gender, Science and Technology (2:1) 65-88.

RAFAELI, A., PRATT, M.G. (1993) Tailored Meanings: On The Meaning and Impact of Organizational Dress, Academy of Management Review (18:1) 32-55.

PRATT, M.G., RAFAELI, A. (1997) Organizational Dress as a Symbol of Multilayered Social Identities, Academy of Management Journal (40:4) 862-98.

RIESSMAN, C.K. (2002) Analysis of Personal Narratives, Handbook of Interview Research: Context \& Method, ed. J.F. Gubrium, J.A. Holstein, Sage, London, 695-710.

RIESSMAN, C.K. (2008) Narrative Methods for the Human Sciences, Sage, LA, London, New Delhi and Singapore.

SIMPSON, P. (2008) Stories, Creative Methods in Organizational Research, ed. M. Broussine, Sage, London, 92-107.

SIMPSON, R. (2009) Men in Caring Occupations: Doing Gender Differently, Palgrave Macmillan, Basingstoke.

SMITH, G., WHITFIELD, T.W.A. (2005) The Professional Status of Designers: A National Survey of How Designers are Perceived, The Design Journal (8:1) 52-60. 
Alındı: 09.12.2012; Son Metin: 03.06.2013

Anahtar Sözcükler: Endüstriyel tasarım; disiplinlerarası çalışma; mesleki statü; ideal çalışan.

\section{ENDÜSTRIYYLL TASARIMCILARIN MESLEKI STATÜLERINDE KURUMLARIN ROLÜ: KILIK KIYAFET NORMLARININ İNCELENMESİ}

Mevcut yazına baktığımızda çok disiplinli iş ortamlarında endüstriyel tasarımcıların düşük bir mesleki statüye sahip olmalarının ele alınan bir konu olduğunu, ancak bu statünün inşasının gerçekleştiği kurumsal bağlamlara yeterince odaklanılmadığını görüyoruz. Bu makale, yazındaki bu boşluğa yanıt olarak, endüstriyel tasarımcının yeni ürün geliştirme süreçlerinde mühendisler ve pazarlamacılarla işbirliği yapmasını gerektiren kurumsal bağlamları incelemektedir. Farklı kurumsal bağlamlarda çalışan endüstriyel tasarımcıların benimsediği kılık kıyafet normları etrafındaki tartışmalara odaklanarak bu normların endüstriyel tasarımcılar ve diğer meslek grupları arasındaki güç ilişkileriyle bağlantısını araştırmaktadır. Bu makalenin görgül dayanağını Türkiye'de çeşitli üretim firmalarında iş deneyimine sahip endüstriyel tasarımcıların yüz yüze görüşmelerde anlattıkları hikayeler oluşturmaktadır. Bu hikayelerin çözümlemeleri bizi şu sonuca götürmektedir: Kurumlar, endüstriyel tasarımın üstün olmayan statüsünü yeniden üretmekte önemli bir rol oynamaktadır. Bunu da özellikle mühendislik ve pazarlama bağlamında benimsenen alışılagelmiş 'resmi ve ciddi profesyonel çalışan' imajını, endüstriyel tasarımcılarla eşleştirilen ve onların gayrıresmi kıyafet tercihleri tarafından da desteklenen alışılmadık mesleki imajın üzerinde tutarak sağlamaktadırlar. Bu tür simgesel eşleştirmeler ve bu eşleştirmelerin sürdürdüğü güç dengesizlikleri, kurumsal hiyerarşi içerisinde endüstriyel tasarımcıları güçlü konumlardan uzaklaştırmaktadır.

PINAR KAYGAN; BID, PhD.

Completed her PhD at the Department of Sociological Studies, University of Sheffield. Her research has focused on industrial design profession and various organizational issues appear around it, with an emphasis on gendering of technology-related work. She is currently teaching at the Department of Industrial Design, Middle East Technical University. 
